\title{
Immunocytochemical characterisation of cutaneous lymphomas other than mycosis fungoides
}

\author{
ELISABETH RALFKIAER, * TA SAATI, $†$ J BOSQ $\ddagger$ G DELSOL, $†$ KC GATTER, \\ DY MASON $\ddagger$
}

From the *Departments of Pathology and Dermatology, The Finsen Institute, University of Copenhagen, Denmark, $\dagger$ Laboratoire Central d'Anatomie Pathologique, CHU Toulouse Purpan, France, and the $\ddagger N u f f i e l d$ Department of Pathology, John Radcliffe Hospital, University of Oxford, England

SUMMARY The immunophenotypic properties of 25 cutaneous non-Hodgkin lymphomas other than mycosis fungoides or Sezary syndrome were investigated and correlated with clinical and histopathological data. The 11 low grade lymphomas were all of B cell origin, whereas the 14 high grade lymphomas comprised B and T cell tumours, true histiocytic proliferations, and one "null" cell lymphoid neoplasm. For the high grade lymphomas correct prediction of the immunological phenotype based on morphological criteria was only possible in three cases. In contrast, all of the low grade lymphomas showed the non-epidermotropic infiltration pattern considered to be characteristic of cutaneous B cell tumours. For these conditions, however, immunophenotypic investigations provided a convenient means of improving discrimination between benign (polyclonal) and malignant (monoclonal) lesions, and also showed similarities with nodal lymphomas in terms of expression of lymphoid subset markers and composition of the non-neoplastic white cell infiltrate. No differences were identified between primary and secondary or concurrent cutaneous and extracutaneous lymphomas.

Cutaneous non-Hodgkin lymphomas other than mycosis fungoides or Sezary syndrome constitute a heterogeneous group of neoplasms and most of these disorders are likely to represent cutaneous equivalents of nodal malignancies. Immunophenotypic investigations form a useful supplement to their histogenetic characterisation and may provide a common conceptual basis for their classification.

It is generally accepted that cutaneous non-Hodgkin lymphomas can be divided into two principal distinct categories on clinical, histopathological, and immunophenotypic criteria-that is, mycosis fungoides or Sezary syndrome and other variants of lymphoma. $^{1-5}$

The mycosis fungoides or Sezary syndrome cases are epidermotropic lymphocytic lymphomas, which originate from $\mathrm{T}$ cells and present (and possibly arise) in the skin. ${ }^{5}$ In the fully developed cases both conditions usually show characteristic clinical pictures, ${ }^{56}$ and they currently form the most well defined entities of the spectrum of disorders known as the cutaneous $\mathrm{T}$ cell lymphomas. ${ }^{7}$

Compared with mycosis fungoides or Sezary syndrome other cutaneous lymphomas constitute an ex-

Accepted for publication 7 January 1986 tremely heterogeneous group of neoplasms. Even though evidence has accumulated that these tumours presumably represent the cutaneous equivalents of nodal non-Hodgkin lymphomas, ${ }^{13}$ uniformly accepted criteria for their histopathological diagnosis and classification have not as yet been established. ${ }^{1-48}$

Immunocytochemical staining techniques have formed a valuable adjunct to the histological diagnosis and classification of nodal lymphoma infiltrates 910 and have provided important insights into $T$ cell subset heterogeneity among cutaneous $T$ cell lymphomas of the mycosis fungoides or Sezary syndrome type. ${ }^{1112}$ Few comprehensive immunophenotypic studies of other categories of cutaneous lymphoma have been reported. In this study the immunophenotypic characteristics of 25 cases of such disorders were investigated and correlated with clinical and histological data. 
Table 1 Monoclonal antibodies

\begin{tabular}{|c|c|c|}
\hline Antibody & Specificity & $\begin{array}{l}\text { Source or reference, } \\
\text { or both }\end{array}$ \\
\hline $\begin{array}{l}\text { DAKO-LC } \\
\text { anti-HLA-DR } \\
\text { B4 } \\
\text { B1 } \\
\text { Tol5/4KB128 } \\
\text { anti-IgM } \\
\text { anti-IgD } \\
\text { anti-lambda } \\
\text { anti-kappa } \\
\text { anti-Leu-5/Lyt3 } \\
\text { anti-Leu-1/Lyt2 } \\
\text { anti-Leu-4 } \\
\text { anti-Leu-3 } \\
\text { anti-Leu-2 } \\
\text { anti-Leu-7 } \\
\text { OKT6 } \\
\text { R4/23 } \\
\text { anti-Leu-M3 } \\
\text { KB90 } \\
\text { EBM11 } \\
\text { FMC32 } \\
\text { OKM1 } \\
\text { My9 } \\
\text { My7 } \\
\text { E29 } \\
\text { KL1 }\end{array}$ & $\begin{array}{l}\text { Leucocyte common antigen } \\
\text { HLA-DR } \\
\text { Pan B cell (CD19)* } \\
\text { Pan B cell (CD20) } \\
\text { Pan B cell (CD22) } \\
\text { IgM } \\
\text { IgD } \\
\lambda \\
\kappa \\
\text { Pan T cell (E rosette receptor) (CD2) } \\
\text { Pan T cell; some normal and malignant B cells (CD5) } \\
\text { Pan T cell (CD3) } \\
\text { T helper and inducer cells; macrophages (CD4) } \\
\text { T suppressor and cytotoxic cells (CD8) } \\
\text { Natural killer cells } \\
\text { Cortical thymocytes; Langerhans' cells (CD1) } \\
\text { Follicular dendritic cells } \\
\text { Macrophages } \\
\text { Macrophages (p150, 95 molecule) } \\
\text { Macrophages } \\
\text { Macrophages } \\
\text { Granulocytes, monocytes, macrophages (C3bi receptor) } \\
\text { Myeloid cells; monocytes } \\
\text { Myeloid cells; moncytes (CDw13) } \\
\text { Epithelial membrane antigen } \\
\text { Keratin }\end{array}$ & $\begin{array}{l}\text { Dako }^{16} \\
\text { BD } \\
\text { CC } \\
\text { CC } \\
\text { Dako } \\
\text { Dako } \\
\text { Dako } \\
\text { Dako } \\
\text { BD } \\
\text { BD/NEN } \\
\text { BD/NEN } 1718 \\
\text { BD } \\
\text { BD } 19 \\
\text { BD } \\
\text { BD } \\
\text { Ortho } \\
\text { Dako } 20 \\
\text { BD } \\
\text { DY Mason } \\
\text { Dako } \\
21 \\
\text { Ortho } \\
22 \\
23 \\
24 \\
25\end{array}$ \\
\hline
\end{tabular}

*CD numbers refer to the antigens defined by the First and Second International Workshops on Human Leucocyte Difierentiation Antigens. Dako = Dakopatts; BD = Becton Dickinson; $\mathbf{C C}=$ Coulter Clone; NEN = New England Nuclear; Ortho = Ortho Diagnostics.

\section{Material and methods}

Twenty five patients with cutaneous non-Hodgkin lymphomas other than mycosis fungoides or Sezary syndrome were investigated. The diagnosis of mycosis fungoides or Sezary syndrome was based on clinical and histopathological criteria, as described previously. ${ }^{5}$

\section{CLINICAL EVALUATION}

Clinical evaluation included physical examination, blood count, chest radiograph, lymphangiography, lymph node biopsy, blood and bone marrow examination, and liver biopsy. Based on the outcome of these investigations the patients were graded in accordance with the Ann Arbor system. ${ }^{13}$

\section{HISTOPATHOLOGICAL EVALUATION}

Routinely processed paraffin embedded skin biopsy specimens were stained both with haematoxylin and eosin and May-Grunewald Giemsa and then classified in accordance with the Kiel classification ${ }^{14}$ and the international working formulation for clinical usage. ${ }^{15}$ An attempt was also made to predict the immunological phenotype of the various infiltrates by assessing the histological infiltration patterns (T; B; non-T, non-B) described by Burg et al. ${ }^{3}$

PROCESSING OF FRESH BIOPSY SPECIMENS

Skin biopsy specimens were frozen and stored in liquid nitrogen. Cryostat sections $(6 \mu \mathrm{m})$ were air dried overnight at room temperature, fixed in acetone for 10 minutes ${ }^{10}$ and either stained immediately or wrapped in aluminium foil and stored at $-20^{\circ} \mathrm{C}$ until staining, when the sections were allowed to warm to room temperature before unwrapping.

\section{ANTIBODIES AND HISTOCHEMICAL REAGENTS}

Table 1 gives details of the monoclonal antibodies used in this study. Rabbit antimyeloperoxidase was a generous gift from Dr I Olsson. Immune complexes of alkaline phosphatase and mouse monoclonal antialkaline phosphatase (APAAP complexes) were pre: pared as described previously. ${ }^{26}$ Unconjugated rabbit antimouse immunoglobulin, peroxidase conjugated rabbit antimouse immunoglobulin, peroxidase conjugated swine antirabbit immunoglobulin, and rabbit antihorseradish peroxidase were all purchased from Dakopatts, Copenhagen, Denmark. Levamisole, diaminobenzidine-tetrahydrochloride, naphthol ASMX, and New Fuchsin were obtained from Sigma.

\section{IMMUNOENZYMATIC STAINING PROCEDURES}

Cryostat sections were incubated with monoclonal antibody and stained using a three stage immunoperoxidase method ${ }^{10}$ or the alkaline phosphatase:antialkaline phosphatase (APAAP) technique. ${ }^{26}$ The polyclonal antibody was stained by a peroxidase:antiperoxidase (PAP) method. ${ }^{9}$ The presence of peroxidase was shown by using di- 
aminobenzidine and hydrogen peroxide, ${ }^{9}$ and alkaline phosphatase by using a naphthol AS-MX-New Fuchsin substrate. ${ }^{26}$ Endogenous tissue alkaline phosphatase activity was inhibited by adding $1 \mathrm{mM}$ levamisole to the substrate solution. ${ }^{26}$ Positive controls were performed by staining benign hyperplastic lymph nodes or tonsils; negative controls by omitting the primary monoclonal or polyclonal antibody.

\section{Results}

Clinical Data (Table 2)

Cases could be divided into: primary cutaneous tumours showing no evidence of extracutaneous disease (eight cases); concurrent cutaneous and extracutaneous lymphomas in which the clinical or histological staging procedures showed nodal or visceral spread, in addition to the cutaneous lesions ( 12 cases); and secondary cutaneous neoplasms (five cases) disseminating to the skin from lymph nodes or bone marrow 12 to 108 months (median: 60 months) after diagnosis.

Men slightly predominated in each of these three groups of patients, and the age distribution was essentially similar among them. The median length of follow up was similar among patients with primary and concurrent cutaneous lymphomas (16 and 15 months, respectively). Whereas six of 12 patients with concurrent cutaneous and extracutaneous lesions died from their disease (with a median survival time of eight months) all but one of the eight patients with primary skin lymphomas are still alive at the time of writing. The overall survival for the patients with secondary cutaneous lymphomas ranged from 15 to 109 months (median: 72 months). Prognosis subsequent to the development of cutaneous lesions in these patients, however, was poor (one to 12 months (median: 4.5 months)).

\section{histological Data (Table 2)}

Eleven tumours were classified as low grade lymphoid malignancies - that is, lymphocytic, centrocytic, centroblastic and centrocytic lymphomas, or immunocytomas. All of these cases showed a B cell infiltration pattern in the form of a distinctive "grenz" zone between epidermis and the dermal infiltrate (Figs. 1 and 2). Follicular areas were identified in three of the germinal centre cell tumours (cases 2-4), while the remaining low grade tumours showed only diffuse infiltration.

The remaining 14 lymphomas were high grade malignancies - that is, centroblastic, immunoblastic, lymphoblastic, or unclassified large cell lymphomas. All these cases showed diffuse infiltrates, and with the exception of cases 5,7 , and 14, their histological infiltration pattern was of the non-T, non-B type (Fig. 3).
The median length of follow up was 16 months for the high grade tumours and 24 months for the low grade malignancies. Nevertheless, whereas 10 of the 14 patients with high grade tumours died from their disease, all but one of the 11 patients with low grade lymphomas are alive at the time of writing, and four are in complete remission.

PHENOTYPIC DATA (Table 3)

Neoplastic cells In all cases the neoplastic cells reacted with antileucocyte common antibody and were negative for epithelial cell markers (keratin, epithelial membrane antigen), confirming their lymphoid origin. Nineteen tumours showed B cell phenotypic properties, three (cases 6, 7, 20) expressed markers characteristic of $\mathrm{T}$ lymphocytes, and two (cases 18 and 24) showed antigenic profiles resembling those found on macrophages. The remaining case (19) was classified as a "null" cell lymphoid malignancy, as the cells were negative not only with antibodies against B cells, $T$ cells, and macrophages, but also with antimyeloid reagents (My9, My7, antimyeloperoxidase) and antibody (anti-Leu-7) against natural killer cells.

All the B cell tumours were positive both for HLADR and for the pan B cell CD19, CD20 or CD22 antigens, identified by antibodies B4, B1, and To15/4KB128, respectively (Fig. 1). Expression of the $T$ cell associated CD5 antigen (recognised by antiLeu-1) was confined to three lymphocytic lymphomas (cases 1, 9, 21; Fig. 1) and two centroblastic and centrocytic tumours (cases 2 and 4). Thirteen of the B cell tumours expressed both heavy and light chains, individual tumours being monotypic for either $\kappa$ or $\lambda$ chains (Fig. 2). The remaining six B cell neoplasms (cases $8,15,17,22,23,25$ ) either lacked detectable immunoglobulin or expressed heavy chains (Fig. 3) in the absence of light chains.

Among $T$ cell lymphomas, two (cases 6, 20) expressed all three pan T cell CD2, CD5, and CD3 antigns recognised by anti-Leu-5/Lyt3, anti-Leu-1/Lyt2, and anti-Leu-4, respectively. In the remaining case (7) a proportion of the tumour cells did not express the CD5 marker. All three T cell tumours resembled peripheral T-helper/inducer cells, being positive for the CD4 antigen (antibody anti-Leu-3) and negative both for CD8 (antibody anti-Leu-2) and CD1 (antibody OKT6). HLA-DR was expressed by a proportion of the tumour cells in all $T$ cell cases.

Both of the macrophage tumours $(18,24)$ expressed HLA-DR and the macrophage associated antigens recognised by antibodies KB90 (anti-p.150,95), EBM11, FMC32, anti-Leu-M3 and/or OKM1 (against the C3bi receptor). Furthermore, both cases showed the strong cytoplasmic positivity for the CD4 marker (anti-Leu-3) characteristic of macrophages. Other anti $T$ cell antibodies and all anti $B$ cell antibodies were consistently negative, except that case 24 
Table 2 Clinical data

\begin{tabular}{lllll}
\hline Case No & Age & Hex & Inflogiltration pattern§
\end{tabular}

istology"

Inflitration pattern§

\begin{tabular}{ccc}
\hline Primary cutaneous lymphomas & \\
1 & 45 & M \\
2 & 61 & M \\
3 & 70 & M \\
4 & 53 & F \\
5 & 54 & F \\
6 & 15 & F \\
7 & 43 & M \\
8 & 67 & M
\end{tabular}

Malignant lymphocytic (sl)

Centroblastic and centrocytic (fm)

Centroblastic and centrocytic (fm)

Centroblastic and centrocytic (fm)

Immunoblastic (IB)

Lymphoblastic (LB)

Unclassified large cell (uncl)

Unclassified large cell (uncl)

Malignant lymphocytic (sl)

Immunocytoma (sl)

Immunocytoma (sl)

Centrocytic (dsc)

Centroblastic and centrocytic (dm)

Centroblastic (dlc)

Immunoblastic (IB)

Lymphoblastic (LB)

Lymphoblastic (LB)

Unclassified large cell (uncl)

Unclassified large cell (uncl)

Unclassified large cell (uncl)

Malignant lymphocytic (sl)

Centroblastic and centrocytic (dm)

Unclassified large cell (uncl)

Unclassified large cell (uncl)

Unclassified large cell (uncl)

B
$\mathbf{B}$
$\mathbf{B}$
$\mathbf{B}$
$\mathbf{B}$
non $\mathrm{T}$, non $\mathrm{B}$
$\mathbf{T}$
non $\mathrm{T}$, non $\mathrm{B}$

B
B
B
B
B
B
non T, non B
non T, non B
non T, non B
non T, non B
non T, non B
non T, non B

B

B

non $T$, non $B$

non $T$, non $B$ non $T$, non $B$

*Kiel classification with corresponding working formulation in parentheses. sl = small lymphocytic lymphoma; fm = follicular lymphoma, mixed sma and large cell, $\mathrm{dsc}=$ diffuse lymphoma, small cleaved cell; dlc = diffuse lymphoma, large cell; dm = diffuse lymphoma, mixed small and large cell uncl = unclassified large cell lymphoma of diffuse type. $\mathbf{I B}=$ immunoblastic; $\mathrm{LB}=$ lymphoblastic.

$+\mathrm{A}+=$ alive with active disease; $A 0=$ alive in remission; $\mathrm{D}+=$ dead from lymphoma.

$\S$ assessed using criteria described by Burg et al. ${ }^{3}$

Table 3 Phenotype of infiltrating malignant cells in skin biopsy specimens from cutaneous non-Hodgkin lymphomas other than mycosis fungoides and Sezary syndrome.

\begin{tabular}{|c|c|c|c|c|c|c|c|}
\hline \multirow[b]{2}{*}{ Case No } & \multirow[b]{2}{*}{ Histology } & \multicolumn{6}{|l|}{ Antibodies } \\
\hline & & Anti-HLA-DR & $\begin{array}{l}\text { Anti-pan-B cell } \\
(C D 19,20,22)\end{array}$ & Anti-IgM & Anti-IgD & Anti-kappa & Anti-lambda응 \\
\hline \multicolumn{8}{|c|}{ Primary cutaneous lymphomas } \\
\hline 1 & Malignant lymphocytic & $++^{*}$ & ++ & ++ & - & - & $+t$ \\
\hline 2 & Centroblastic and centrocytic & ++ & $+t$ & $+t$ & - & ++ & - \\
\hline 3 & Centroblastic and centrocytic & $+t$ & ND & ++ & - & $+t$ & - \\
\hline 4 & Centroblastic and centrocytic & $+t$ & $+t$ & ++ & + & $+t$ & - \\
\hline 5 & Immunoblastic & $+t$ & ++ & $+t$ & - & $t+$ & - \\
\hline 6 & Lymphoblastic & ++ & - & - & - & - & - \\
\hline 7 & Unclassified large cell & + & - & ND & ND & ND & ND \\
\hline 8 & Unclassified large cell & $+t$ & ++ & - & - & - & - \\
\hline \multicolumn{8}{|c|}{ Concurrent cutaneous and extracutaneous lymphomas } \\
\hline 9 & Malignant lymphocytic & ++ & ++ & ++ & $+t$ & $+t$ & - \\
\hline 10 & Immunocytoma & ++ & ++ & ++ & - & ++ & - \\
\hline 11 & Immunocytoma & $+t$ & $+t$ & ++ & - & - & ++ \\
\hline 12 & Centrocytic & ++ & ++ & ++ & - & - & ++ \\
\hline 13 & Centroblastic and centrocytic & ++ & ND & ++ & ++ & ++ & - \\
\hline 14 & Centroblastic & $+t$ & ++ & ++ & - & ++ & - \\
\hline 15 & Immunoblastic & ++ & $+t$ & - & - & - & - \\
\hline 16 & Lymphoblastic & ++ & ++ & ++ & - & $+t$ & - \\
\hline 17 & Lymphoblastic & ++ & $+t$ & + & + & - & - \\
\hline 18 & Unclassified large cell & ++ & - & - & - & - & - \\
\hline 19 & Unclassified large cell & ++ & - & - & - & - & - \\
\hline 20 & Unclassified large cell & + & - & ND & ND & - & - \\
\hline \multicolumn{8}{|c|}{ Secondary cutaneous lymphomas } \\
\hline 21 & Malignant lymphocytic & ++ & ++ & ++ & ++ & - & ++ \\
\hline 22 & Centroblastic and centrocytic & $+t$ & ++ & - & + & - & - \\
\hline 23 & Unclassified large cell & ++ & $+t$ & - & - & - & - \\
\hline 24 & Unclassified large cell & $+t$ & - & - & - & - & - \\
\hline 25 & Unclassified large cell & ++ & + & - & - & - & - \\
\hline
\end{tabular}

$\mathrm{L}=$ lambda; $\mathrm{Ig}-=$ immunoglobulin negative); $\mathrm{T}(\mathrm{H})=\mathrm{T}$ cell lymphoma of helper/inducer type; $\mathrm{M}=$ macrophage tumour; "null" $=$ null cell lymphoid malignancy; $\mathbf{H X}=$ histiocytosis $\mathrm{X}$ like.

$*++=$ labelling of most $(>50 \%)$ of the cells; $+=$ labelling of a proportion $(20-50 \%)$ of the cells; $+/-=$ labelling of a few $(5-10 \%)$ of the cells; $-=$ negative or only occasional cells positive; $\mathrm{ND}=$ not done. 


\begin{tabular}{|c|c|c|c|c|c|}
\hline Actual phenotype & Stage & $\begin{array}{l}\text { Duration of } \\
\text { disease before } \\
\text { cutaneous spread } \\
\text { (months) }\end{array}$ & Treatment & $\begin{array}{l}\text { Follow up } \\
\text { (months) }\end{array}$ & $\begin{array}{l}\text { Present } \\
\text { condition! }\end{array}$ \\
\hline $\begin{array}{l}\text { B cell } \\
\text { B cell } \\
\text { B cell } \\
\text { B cell } \\
\text { B cell } \\
\text { T cell } \\
\text { T cell } \\
\text { B cell }\end{array}$ & $\begin{array}{l}\text { Ie } \\
\text { Ie } \\
\text { Ie } \\
\text { le } \\
\text { le } \\
\text { Ie } \\
\text { Ie } \\
\text { Ie }\end{array}$ & & $\begin{array}{l}\text { None } \\
\text { chemotherapy } \\
\text { chemotherapy } \\
\text { X-ray treatment } \\
\text { X-ray treatment } \\
\text { chemotherapy } \\
\text { X-ray treatment } \\
\text { chemotherapy }\end{array}$ & $\begin{array}{r}14 \\
54 \\
88 \\
2 \\
36 \\
14 \\
7 \\
18\end{array}$ & $\begin{array}{l}\text { A+ } \\
\text { Ao } \\
\text { Ao } \\
\text { A+ } \\
\text { D+ } \\
\text { A+ } \\
\text { A+ } \\
\text { Ao }\end{array}$ \\
\hline $\begin{array}{l}\text { B cell } \\
\text { B cell } \\
\text { B cell } \\
\text { B cell } \\
\text { B cell } \\
\text { B cell } \\
\text { B cell } \\
\text { B cell } \\
\text { B cell } \\
\text { Macrophage } \\
\text { Null cell lymphoid neoplasm } \\
\text { T cell }\end{array}$ & $\begin{array}{l}\text { IV } \\
\text { IV } \\
\text { IV } \\
\text { IV } \\
\text { IV } \\
\text { IV } \\
\text { III } \\
\text { IV } \\
\text { IV } \\
\text { IV } \\
\text { IV } \\
\text { IV }\end{array}$ & & $\begin{array}{l}\text { chemotherapy } \\
\text { chemotherapy } \\
\text { chemotherapy; X-ray treatment } \\
\text { chemotherapy } \\
\text { chemotherapy } \\
\text { None } \\
\text { chemotherapy; X-ray treatment } \\
\text { chemotherapy } \\
\text { chemotherapy } \\
\text { chemotherapy } \\
\text { chemotherapy } \\
\text { chemotherapy; X-ray treatment }\end{array}$ & $\begin{array}{c}24 \\
42 \\
8 \\
16 \\
18 \\
0 \cdot 5 \\
7 \\
21 \\
8 \\
14 \\
60 \\
9\end{array}$ & $\begin{array}{l}\text { A+ } \\
\text { Ao } \\
\text { A+ } \\
\text { A+ } \\
\text { Ao } \\
\text { D+ } \\
\text { D+ } \\
\text { A+ } \\
\text { D+ } \\
\text { D+ } \\
\text { D+ } \\
\text { D+ }\end{array}$ \\
\hline $\begin{array}{l}\text { B cell } \\
\text { B cell } \\
\text { B cell } \\
\text { Histiocytosis X like } \\
\text { B cell }\end{array}$ & $\begin{array}{l}\text { IV } \\
\text { IV } \\
\text { IV } \\
\text { IV } \\
\text { III }\end{array}$ & $\begin{array}{r}60 \\
72 \\
108 \\
12 \\
14\end{array}$ & $\begin{array}{l}\text { chemotherapy } \\
\text { X-ray treatment } \\
\text { chemotherapy } \\
\text { chemotherapy } \\
\text { chemotherapy }\end{array}$ & $\begin{array}{r}72 \\
90 \\
109 \\
15 \\
20\end{array}$ & $\begin{array}{l}\mathrm{D}+ \\
\mathrm{A}+ \\
\mathrm{D}+ \\
\mathrm{D}+ \\
\mathrm{D}+\end{array}$ \\
\hline
\end{tabular}

Anti-pan-T cell (CD2, 3)

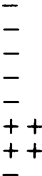

$+$
Anti-pan-T cell (CD5)

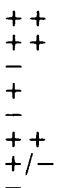

$+$$$
-
$$$$
-
$$$$
-
$$$$
\text { - }
$$$$
\text { - }
$$$$
-
$$$$
\text { - }
$$$$
++
$$$$
++
$$$$
-
$$$$
-
$$

Anti-T helper (CD4)

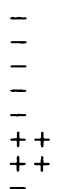

$-$

$-$

$-$

-

$-$

$-$

$++$

$+$

-
-
+
Anti-T suppressor (CD8)

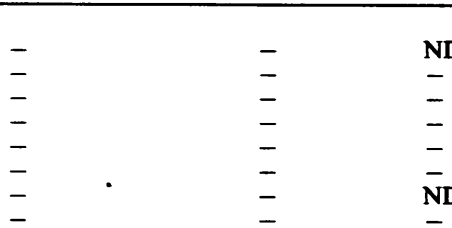

B (ML)

B (MK)

B (MK)

B (MDK)

B (MK)

$\mathrm{T}$ (H)

$T$ (H)

B (Ig-)

-

ND

B (MDK)

B (MK)

B (ML)

B (ML)

B (MDK)

B (MK)

B (Ig-)

B (MK)

B (MD)

M

"null"

T (H)

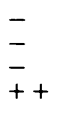

ND

ND

$+$

B (MDL)

$B$ (D)

B (Ig-)

B (Ig-) 


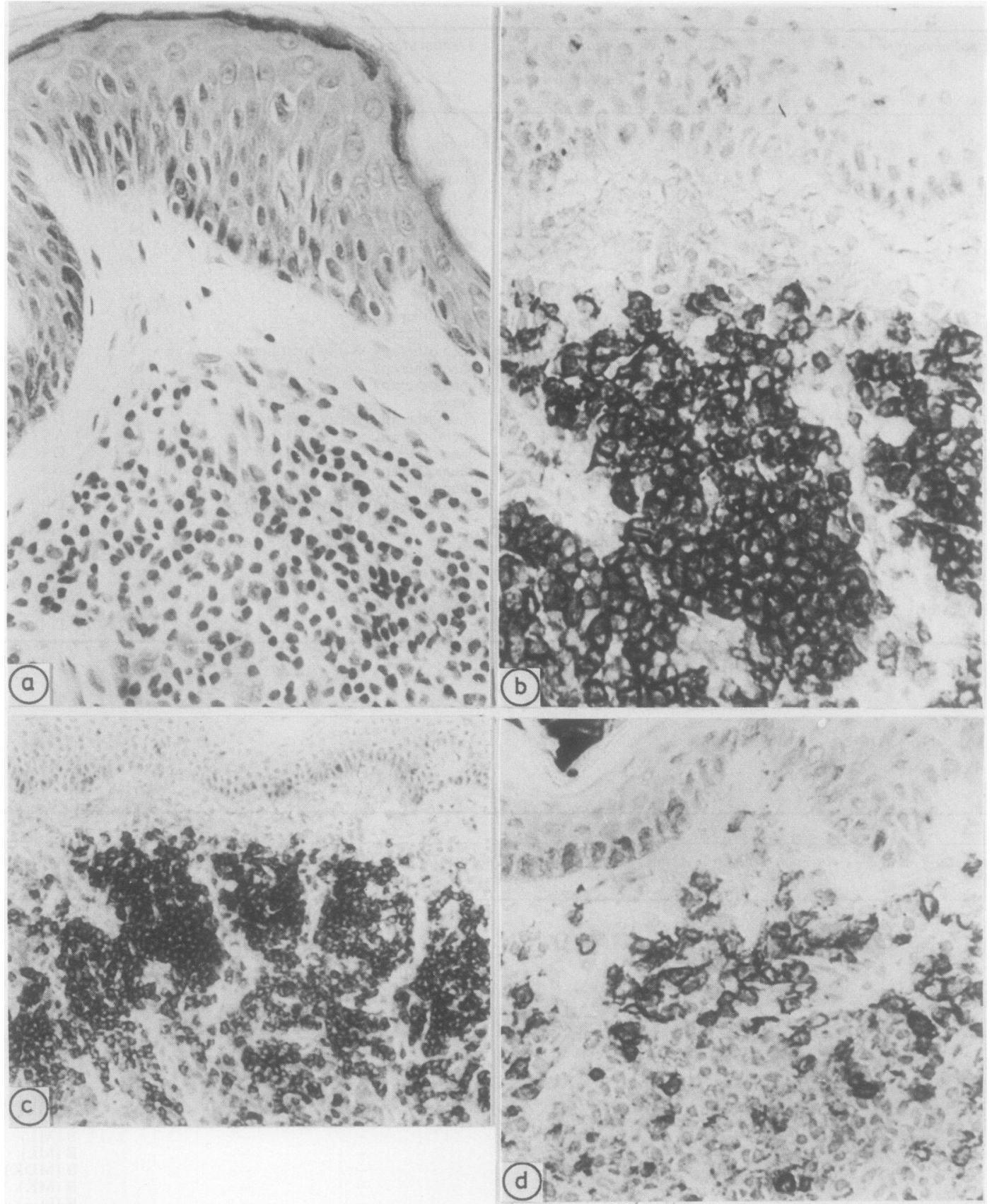

Fig. 1 Lymphocytic lymphoma showing (a) non-epidermotropic B cell infiltration pattern with distinctive "grenz" zone. (Haematoxylin and eosin.) Neoplastic cells are strongly positive for $T$ cell associated CDS marker $(b)$, in addition to pan B cell CD 22 antigen (c). Staining for pan T cell CD3 antigen is confined to surrounding reactive $T$ lymphocytes (d). All Figs. $\times 400$, except (c) $\times 200$. 


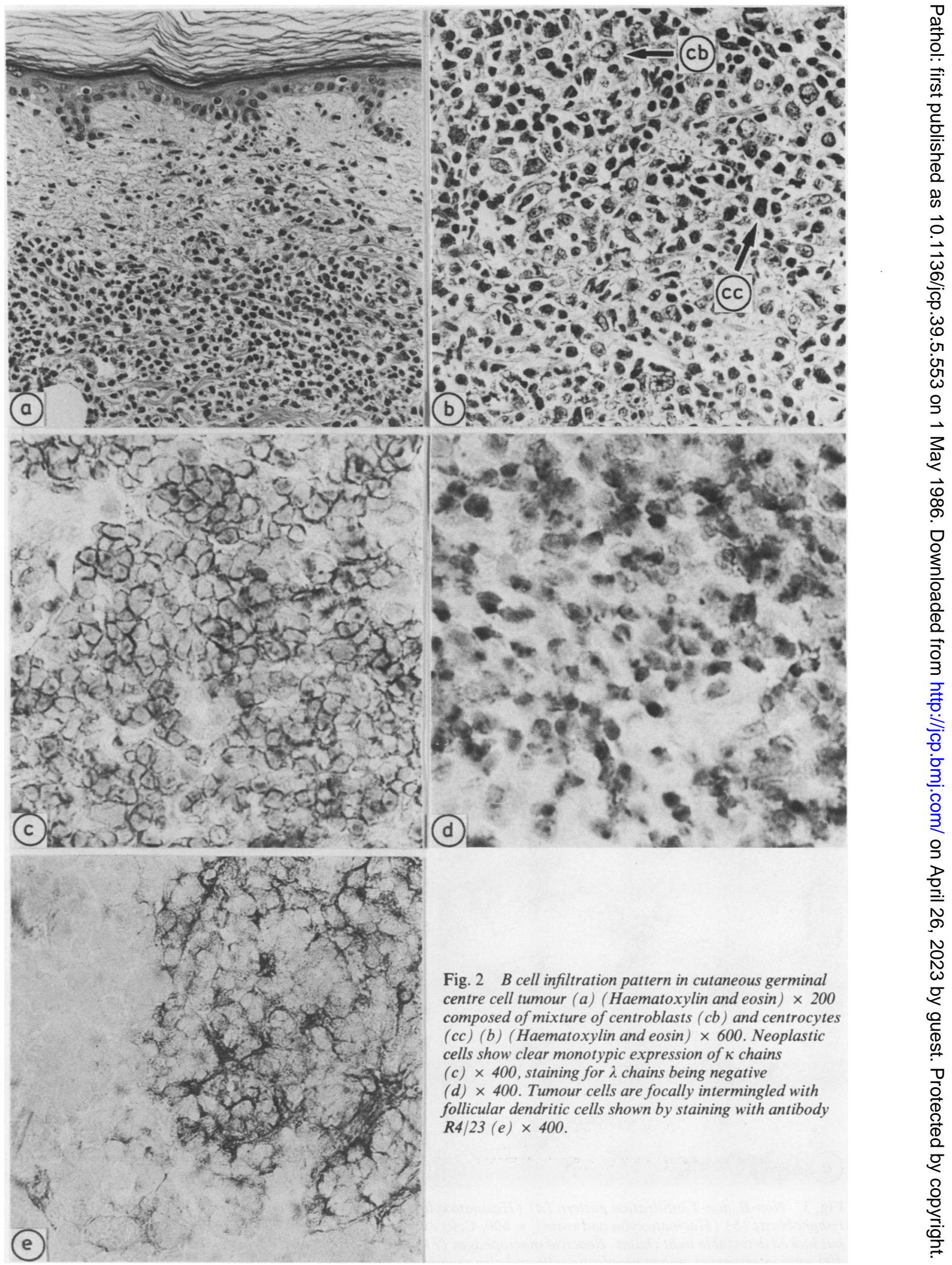




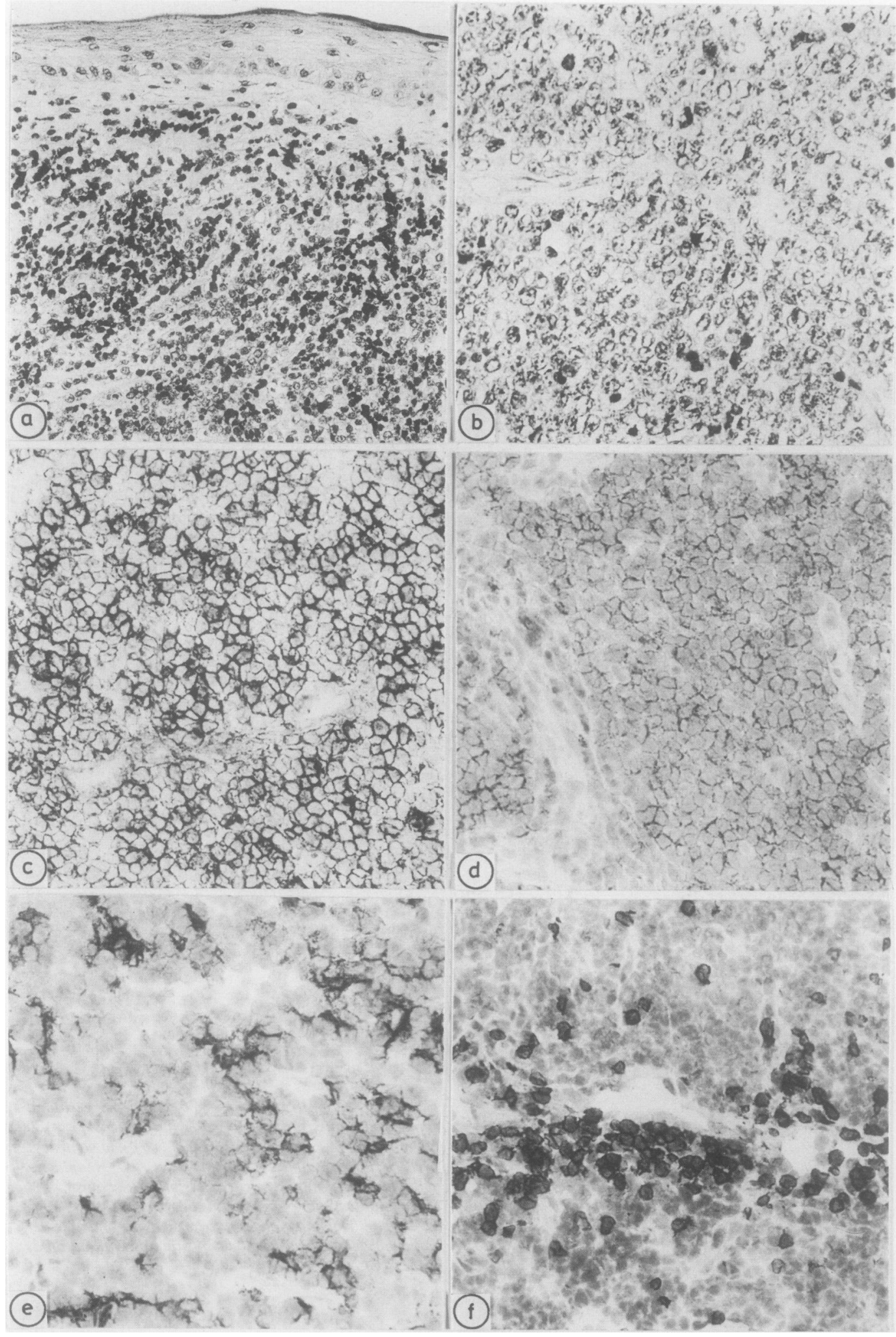

Fig. 3 Non-B, non-T infiltration pattern (a) (Haematoxylin and eosin) $\times 200$ in high grade lymphoma composed of lymphoblasts (b) (Haematoxylin and eosin) $\times 600$. Cells expressed IgM (c) $\times 400$ and more weakly IgD (d) $\times 400$, but lacked detectable light chains. Reactive macrophages $(e)(K B 90) \times 400$ and Tlymphocytes $(f)($ anti-Leu-4) $\times$ 400 were interspersed among neoplastic cells and also showed clustering around blood vessels. 
expressed the CD1 antigen found on cortical thymocytes and Langerhans' cells. This histiocytosis $\mathbf{X}$ like tumour did not show any specific clinical features, such as lytic bone lesions.

Non-neoplastic white cell types Follicular dendritic cells (Fig. 2) were confined to the B cell tumours, being found in one of two immunocytomas (case 10) and in all centrocytic (12) and centroblastic and centrocytic tumours (cases $2-4,13,22$ ), whereas tissue macrophages (Fig. 3) and Langerhans' cells were present in all the infiltrates.

Reactive $\mathrm{T}$ lymphocytes were also present in all lesions and in high grade tumours often clustered close to blood vessels (Fig. 3). Fig. 4 shows the ratio between $T$ helper/inducer and $T$ suppressor/cytotoxic cells in the cutaneous B cell tumours. Most of the germinal centre cell tumours showed a predominance of $\mathrm{T}$ helper lymphocytes, whereas the remaining $\mathrm{B}$ cell lymphoma subtypes did not show any consistent ratio between $T$ helper and $T$ suppressor cells.

Anti-Leu-7 (reactive with a peripheral white cell population which includes natural killer cells) labelled cells in some of the infiltrates but was usually present in low numbers.

\section{CORRELATION BETWEEN PHENOTYPIC,} CLINICAL, AND HISTOLOGICAL DATA

(Tables 2 and 3)

The incidence of individual histopathological and immunophenotypic lymphoma subtypes was essentially similar among primary, concurrent, and secondary cutaneous neoplasms. In keeping with their nonepidermotropic histological infiltration patterns, all of the low grade lymphomas were of B cell origin. Accordingly, the high grade tumours accounted for the entire range of immunophenotypic heterogeneity found in the present material. For these lesions pre-

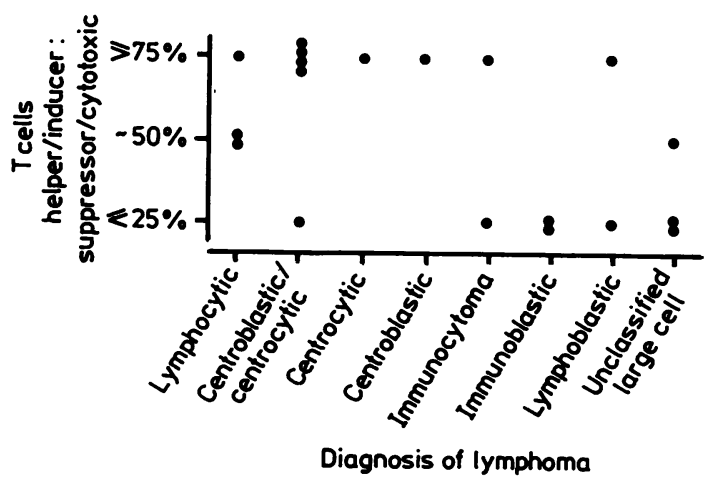

Fig. 4 Ratio between reactive $T$ cells of helper and inducer and suppressor and cytotoxic type in cutaneous $B$ cell lymphomas. diction of a correct immunological phenotype based on morphological criteria was only possible in three cases $(5,7,14)$.

\section{Discussion}

The results indicate that cutaneous non-Hodgkin lymphomas other than mycosis fungoides or Sezary syndrome constitute an extremely heterogeneous group of neoplasms in terms of their histopathological characteristics and immunophenotypic properties, and also substantiate that these disorders can be divided into three main categories on clinical criteria: primary, concurrent, and secondary cutaneous neoplasms. ${ }^{4}$

Detailed immunophenotypic data on a comparable series of patients have been provided in only one previous report, ${ }^{4}$ whereas other phenotypic investigations have used different clinical or histopathological selection criteria, less extensive antibody panels, polyclonal reagents, rosetting methods or enzyme cytochemical rather than immunological techniques. ${ }^{327-29}$ Nevertheless, some general trends can be deduced, and these agree with the present study. These include the observed predominance of B cell tumours among cutaneous low grade lymphomas other than mycosis fungoides or Sezary syndrome ${ }^{34}$ and the quite extensive immunological heterogeneity found among the high grade lymphomas, ${ }^{3417}$ which either resembled B cells, $\mathrm{T}$ cells, macrophages, or (more rarely) so called "null" lymphocytes. It is uncertain whether the "null" lymphocyte phenotype reflects neoplastic proliferation of immature precursor cells devoid of the range of lineage associated markers assessed in this study, or whether it results from diminished or changed antigen expression on malignant as opposed to normal lymphoid cells (although there is indirect evidence in favour of the second possibility). ${ }^{1011}$

The finding that some of the cutaneous high grade tumours in the present material seemed clearly to be of macrophage rather than of lymphoid origin is also in keeping with a previous study, ${ }^{28}$ and it has even been proposed that true histiocytic proliferations account for most cutaneous large cell lymphomas. ${ }^{28}$ Although our data do not substantiate this suggestion, they indicate that macrophage derived tumours may occur more often in the skin than in lymphoid organs. It is also evident, however, that these tumours are not homogeneous as they include both neoplasms that resemble "ordinary" tissue macrophages 1921 and also tumours showing an antigenic profile similar to that of Langerhans' cells (positivity both for macrophage associated antigens and for the CDI marker). ${ }^{30}$ Although this phenotype is very characteristic of the typical histiocytosis $\mathrm{X}$ cases 
seen in infants and children, ${ }^{1931}$ it has also been identified in a limited number of elderly patients with disease confined to nodal or cutaneous areas. ${ }^{32}$ This suggests that histiocytosis $\mathrm{X}$ like proliferations may encompass a broader spectrum of disorders than has been generally accepted in the past. ${ }^{32}$

The overall tendency towards a more favourable prognosis among primary as opposed to concurrent and secondary cutaneous lymphomas and among low as opposed to high grade tumours is in keeping with previous reports $^{12}$ and supports the concept that the extent of these neoplasms and also their histological subtype are important prognostic variables. Even though it has been proposed that cutaneous tumours of different histogenesis may show differences in clinical behaviour or response to treatment, ${ }^{2728}$ there is as yet no definite evidence that the tumour phenotype has independent prognostic importance. With the possible exception of the macrophage tumours mentioned above, however, there has not been any indication that cutaneous tumours differ appreciably from those seen in lymph nodes. Accordingly, we assume that immunological heterogeneity is likely to have similar prognostic implications for cutaneous and nodal neoplasms. ${ }^{33}$ Immunophenotypic investigations should therefore be used routinely as an adjunct to the histological classification of cutaneous high grade lymphomas, as present and previous studies $^{34}$ show that the immunological phenotype of most of these lesions cannot be predicted morphologically. Furthermore, these methods form an obvious and very convenient means of improving the controversial histopathological distinction ${ }^{8}$ between benign (polyclonal ${ }^{34}$ ) and malignant (monoclonal) cutaneous B cell infiltrates.

In spite of the fact that cutaneous lymphomas in this and previous studies ${ }^{14}$ have usually resembled nodal non-Hodgkin lymphomas, none of the currently available classification schemes for nodal lymphomas has been generally adopted for cutaneous infiltrates. ${ }^{3}$ Another major application for immunophenotypic investigations is therefore to test the hypothesis that cutaneous and nodal lymphomas are essentially identical in origin, thus providing a common conceptual basis for their classification. This applies both to high and low grade lymphomas. In particular, even though the B or T cell lineage of low grade lymphomas can usually be determined by assessment of their histological infiltration patterns, ${ }^{3}$ heterogeneity among these conditions in terms of expression of lymphoid subset markers can only be shown by immunophenotypic techniques (which also show the nature and origin of associated nonneoplastic white cells). The conceptual importance of these aspects is illustrated by the following two observations, both of which support the view that cutane- ous and nodal lymphomas are essentially similar. First, the cutaneous B cell tumours positive for the $T$ cell associated CD5 antigen (recognised by antibody anti-Leu-1) showed the same cytological characteristics as anti-Leu-1-positive nodal B cell malignancies. ${ }^{13}$ is Second, the cutaneous germinal centre cell lymphomas contained non-neoplastic white cell types (follicular dendritic cells, $T$ cell subsets similar to those found in corresponding nodal malignancies. ${ }^{20} 2935$

This study indicates that cutaneous non-Hodgkin lymphomas other than mycosis fungoides or Sezary syndrome constitute a heterogeneous group of neoplasms and supports the concept that most of these tumours represent cutaneous equivalents of nodal lymphoma subtypes. Use of immunophenotypic methods forms a valuable supplement to their histogenetic characterisation and may assist in providing uniform criteria for their classification.

The expert technical help of Lotte Laustsen is gratefully acknowledged. The study was supported by grants from the Danish Cancer Society (no 5/83), Institut Nationale de la Santé et de la Recherche Medicale (no 832013), the Wellcome Trust, and the Leukaemia Research Fund. We are indebted to all those referred to in Table 1 for providing monoclonal antibodies for this study. Rabbit antimyeloperoxidase was a generous gift from $\mathrm{Dr}$ I Olsson.

\section{References}

${ }^{1}$ Burke JS, Hoppe RT, Cibull ML, Dorfman RF. Cutaneous malignant lymphoma: a pathological study of 50 cases with clinical analysis of 37. Cancer 1981;47:300-10.

${ }^{2}$ Long JC, Mihm MC, Qazi R. Malignant lymphoma of the skin. A clinicopathological study of lymphoma other than mycosis fungoides diagnosed by skin biopsy. Cancer 1976;38:1282-96.

${ }^{3}$ Burg G, Braun-Falco O, in collaboration with Kerl H, Leder L-D, Schmoeckel C, Wolff HH. Cutaneous lymphomas, pseudolymphomas and related disorders. Heidelberg: Springer-Verlag, 1983.

4 Wood GS, Burke JS, Horning S, Doggett RS, Levy R, Warnke RA. The immunological and clinicopathological heterogeneity of cutaneous lymphomas other than Mycosis fungoides. Blood 1983;62:464-72.

s Slater DN. Lymphoproliferative conditions of the skin. In: Antony PP, MacSween R, eds. Recent advances in histopathology. Edinburgh: Churchill-Livingstone, 1984:83-110.

${ }^{6}$ Thomsen K. Scandinavian Mycosis fungoides trial. In: Goos M, Christophers E, eds. Lymphoproliferative diseases of the skin. Heidelberg: Springer-Verlag, 1982:266-9.

${ }^{7}$ Edelson RL. Cutaneous $\mathrm{T}$ cell lymphoma: Mycosis fungoides, Sezary syndrome, and other variants. J Am Acad Dermatol 1980; 2:89-106.

${ }^{8}$ Evans HL, Winkelmann RK, Banks PM. Differential diagnosis of malignant and benign cutaneous lymphoid infiltrates. A study of 57 cases in which malignant lymphoma had been diagnosed or suspected in the skin. Cancer 1979;44:699-717. 
${ }^{9}$ Stein H, Bonk A, Tolksdorf G, Lennert K, Rodt H, Gerdes J. Immunohistological analysis of the organization of normal lymphoid tissue and non-Hodgkin's lymphomas. J Histochem Cytochem 1980;28:746-60.

${ }^{10}$ Stein H, Lennert K, Feller AC, Mason DY. Immunohistological analysis of human lymphoma: correlation of histological and immunological categories. Adv Cancer Res 1984;42:67-147.

${ }^{11}$ Ralfkiaer E, Lange Wantzin G, Mason DY, Hou-Jensen K, Stein H, Thomsen K. Phenotypic characterization of lymphocyte subsets in Mycosis fungoides: comparison with large plaque parapsoriasis and benign chronic dermatoses. Am J Clin Pathol 1985;84:610-19.

12 Ralfkiaer E, Lange Wantzin G, Larsen JK, et al. Sezary syndrome: phenotypic and functional characterization of the neoplastic cells. Scand J Haematol 1985;34:385-93.

${ }^{13}$ Carbone PP, Kaplan HS, Musshof K, Smithers DW, Tubiana M. Report of the committee on Hodgkin's disease staging classification. Cancer Res 1971;31:1860-1.

${ }^{14}$ Lennert K, in collaboration with Mohri N, Stein H, Kaiserling E, Muller-Hermelink HK. Malignant lymphomas other than Hodgkin's disease. Heidelberg: Springer-Verlag, 1978.

15 The non-Hodgkin's lymphoma pathologic classification group. National Cancer Institute sponsored study of classification of non-Hodgkin's lymphomas. Summary and description of a working formulation for clinical usage. Cancer 1982;49: 2112-35.

${ }^{16}$ Warnke RA, Gatter KC, Falini B, et al. Diagnosis of human lymphoma with monoclonal antileukocyte antibodies. $N$ Engl J Med 1983;309:1275-81.

${ }^{17}$ Burns BF, Warnke RA, Doggett RS, Rouse RV. Expression of a T-cell antigen (Leu-1) by B-cell lymphomas. Am J Pathol 1983;113:165-71.

${ }^{18}$ Al Saati T, Laurent G, Caveriviere P, Rigal F, Delsol G. Reactivity of Leu-1 and T101 monoclonal antibodies with B cell lymphomas (correlation with other immunological markers). Clin Exp Immunol 1984;58:631-8.

${ }^{19}$ Wood GS, Warner NL, Warnke RA. Anti-Leu3/T4 antibodies react with cells of monocyte/macrophage and Langerhans lineage. J Immunol 1983;131:1275-81.

${ }^{20}$ Naiem M, Gerdes J, Abdulaziz Z, Stein H, Mason DY. Production of a monoclonal antibody reactive with human dendritic reticulum cells and its use in the immunohistological analysis of lymphoid tissue. J Clin Pathol 1983;36:167-75.

${ }^{21}$ Hancock WW, Zola H, Atkins RC. Antigenic heterogeneity of human mononuclear phagocytes: immunohistological analysis using monoclonal antibodies. Blood 1983;62:1271-9.

${ }^{22}$ Griffin JD, Linch D, Sabbath K, Larcom P, Schlossman SF. A monoclonal antibody reactive with normal and leukemic human myeloid progenitor cells. Leuk Res 1984;8:521-34.
${ }^{23}$ Griffin J, Mayer RJ, Weinstein HJ, et al. Surface marker analysis of acute myeloblastic leukaemia: identification of differentiation associated phenotypes. Blood 1983;62:557-63.

${ }^{24}$ Delsol G, Gatter KC, Stein H, et al. Human lymphoid cells express epithelial membrane antigen. Lancet 1984;ii:1124-8.

${ }^{25}$ Viac J, Reano A, Brochier J, Staquet M-J, Thivolet J. Reactivity pattern of a monoclonal antikeratin antibody (KL1). J Invest Dermatol 1983;81:351-4.

${ }^{26}$ Cordell JL, Falini B, Erber W, et al. Immunoenzymatic labelling of monoclonal antibodies using immune complexes of alkaline phosphates and monoclonal anti-alkaline phosphatase (APAAP complexes). J Histochem Cytochem 1984;32:219-29.

${ }^{27}$ Krishnan J, Li C-Y, Daniel WP. Cutaneous lymphomas: correlation of histochemical and immunohistochemical characteristics and clinicopathological features. Am J Clin Pathol 1983; 79:157-65.

${ }^{28}$ Willemze R, Ruiter DJ, van Vloten WA, Meijer CJLM. Reticulum cell sarcomas (large cell lymphomas) presenting in the skin. High frequency of true histiocytic tumours. Cancer 1982;50:1367-79.

${ }^{29}$ Willemze R, De Graaff-Reitsma CB, Van Vloten WA, Meijer CJLM. The cell population of cutaneous B-cell lymphomas. Br J Dermatol 1983;108:395-400.

${ }^{30}$ Ralfkiaer E, Stein H, Plesner T, Hou-Jensen K, Mason DY. In situ immunological characterization of Langerhans cells with monoclonal antibodies: comparison with other dendritic cells in skin and lymph nodes. Virchows Arch (Pathol Anat) 1984;403: 401-12.

${ }^{31}$ Thomas JA, Janossy G, Chilosi M, Pritchard J, Pincott JR. Combined immunological and histochemical analysis of skin and lymph node lesions in histiocytosis X. J Clin Pathol 1982; 35:327-37.

${ }^{32}$ Slater DN, Rooney N, Harrington C, et al. Generalized histiocytosis $\mathrm{X}$ in the elderly: a light and electron microscope and monoclonal antibody study. Histopathology 1984;8:927-36.

${ }^{33}$ Kruger GRF. Concepts of lymphoma classification. J Dermatol Surg Oncol 1984;10:247-54.

${ }^{34}$ Ralfkiaer E, Lange Wantzin G, Mason DY, Stein H, Thomsen K. Characterization of benign cutaneous lymphocytic infiltrates by monoclonal antibodies. $\mathrm{Br} J$ Dermatol 1984;111:635-45.

${ }^{35}$ Ancelin E, Delsol G, Familiades, et al. In situ immunological characterization of follicular lymphomas. Hematological Oncology 1984;2:221-37.

Request for reprints to: Dr Elisabeth Ralfkiaer, Department of Pathology, the Finsen Institute, University of Copenhagen, 49 Strandboulevarden, DK-2100 Copenhagen $\varnothing$, Denmark. 